Volume and Issues Obtainable at Center for Sustainability Research and Consultancy
Journal of Business and Social Review in Emerging Economies
ISSN: 2519-089X (E): 2519-0326
Volume 6: Issue 2 June 2020
JSRᄃ
Journal homepage: www.publishing.globalcsrc.org/jbsee

\title{
Perceptions of Elementary School Teachers about Effect of Physical and Emotional Violence on Students' Performance
}

\section{${ }^{1}$ Misbah Malik, ${ }^{2}$ Sumaira Munawar, ${ }^{3}$ Khadija Sittar}

${ }^{1}$ Lecturer, Institute of Education and Research, University of the Punjab Lahore, Pakistan, misbah.ier@pu.edu.pk

${ }^{2}$ Assistant Professor, Lahore Leads University, Lahore Pakistan, sumairamunawar16@gmaul.com

${ }^{3}$ Assistant Professor, Lahore Leads University, Lahore Pakistan, khadijasittar@gmail.com

\begin{abstract}
ARTICLE DETAILS
History

Revised format: May 2019

Available Online: June 2020

Keywords

Emotional violence, physical

violence, academic performance
\end{abstract}

JEL Classification

M12, M29

\begin{abstract}
Physical and emotional violence has become a serious problem in schools.

Teachers are important part of the whole education system, therefore, their insights into school violence are essential to understand the problem. This study aimed to investigate the teachers' perceptions about the effect of physical and emotional violence on students' academic performance. A causal-comparative research design based on a cross-sectional survey was used. A self-developed and validated questionnaire was used to measure the level of teachers' perceptions about physical and emotional violence and its effect on students' academic performance. The reliability index (Cronbach's alpha) of the questionnaire was 0.92. All the teachers of the public high schools of Lahore city were the population of the study. A sample of 300 teachers was taken through simple random sampling technique. Data were analyzed by applying descriptive and inferential statistics. The results revealed that teachers thought that many practices related to emotional and physical violence had positive effects on students' performance. Majority of the teachers responded that they had to use many of the practices in order to put students' attention towards their learning which ultimately improved their performance. Result of correlation analysis also confirmed that teachers' practices related to physical and emotional violence were positively associated with students' academic performance. It was also found that the physical and emotional violence was a significant predictor of students' academic performance. On the basis of these results, it is recommended that school education department should conduct seminars and training workshops to educate teachers about negative effects of violent practices they are using to improve students' performance.
\end{abstract}

(C) 2020 The authors, under a Creative Commons AttributionNonCommercial 4.0

Corresponding author's email address: misbah.ier@pu.edu.pk

Recommended citation: Malik, M., Munawar, S., and Sittar, K. (2020). Perceptions of Elementary School Teachers about Effect of Physical and Emotional Violence on Students' Performance. Journal of Business and Social Review in Emerging Economies, 6(2), 661-667 


\section{Introduction}

Violence is complex and multi faceted phenomenon. There are many types of violence i.e. psychological, physical, emotional and sexual violence. According to Elliot, Hamburg and Williams (1998) violence is a subset of behaviour and its outcomes. Different terms like emotional maltreatment, psychological, verbal and emotional abuse are using interchangeably for violence. Another term related to physical violence is corporal punishment which is specifically used in academic setting. It may be defined as any sort of physical harm which causes physical pain or injuries. In academic setting corporal punishment is used to stop students' misconduct and undesirable behaviours.

Hoffman (1996) stressed that most of the problems related to personal and interpersonal concerns in community are based on violence. Problems always have negative effects on wellbeing and performance of individuals. School is an important part of students' life. Events taking place in school have profound effects not only on their life outside school but also keep on affecting their rest of the life. While researching on violence, Akiba (2001); Coleman (1966); Elliot (1998); Flannery (2006) found the causes of violence in family composition, community violence, ethnicity, students' ages, social and psychological distresses. These factors vary from school to school, community to community or nation to nation.

Physical and emotional health of a child is damaged due to the violence from family members, peers and teachers. Childs' social and moral development is also jeopardized because of psychological, and emotional violence like shouting, coarse behaviour and criticizing harshly. A longitudinal meta-analysis study recently concluded that there is trivial but significant correlation between corporal punishment and students' internal and external problems (Anderson, Berkowitz, Donnerstein, Huesmann, Johnson, Linz,Malamuth \& Wartella, 2003). Many students within school environment face abusive behaviour of their teachers. Şahbal, Sema, and Sevgi (2016) argued that the violence inflicted by the school staff is generally ignored but peer violence is being highlighted. Students are vulnerable to expose to sexual, emotional and physical abuses of school staff (Beyene, Chojenta, Roba, Melka, \& Loxton, 2019; Ward, Artz, Leoschut, Kassanjee, \& Burton, 2018).

The developed countries like United States and England do not allow corporal punishments in order to change and modify students' misconduct. In 1979, Sweden banned corporal punishment first time in the world, whereas many countries did not stop this punishment even today. It is found that the corporal punishment given to children at home, school and outside the school, creates violence and aggression among them. A long term negative effect of school staff violence has created aggression in children (Morales Vasco, 2019).

Students' social and psychological skills get affected by school and teachers' behaviour. The peers set a model based on showing respect, empathy and conflict resolution skills by their teachers because teachers have significant role of acquiring these features (Chen \& Astor, 2011).The students tend to stay away from the teacher who always show maltreatment in the class and never respect that teacher, but they have fear and aggression for that teacher. It also upset teacher-student relationships. Şahbal, Sema, and Sevgi TIMBIL (2016) claimed that students' progress may get influenced by instigating fear, atrocity, enmity, low confidence, instability, communicational issues, abhorrence of power, issues in companion dealings, and academic issues which lead to the advancement of mental issue like sleep related problems, xenophobia, sorrow, and uneasiness when they are observers or sufferers of savagery from others who are accountable for securing, supporting, and facilitating them.

According to Crawage (2005) school violence is "the use of supremacy in school or its related settings by any person, organization, or through any societal practice. Prinsloo and Neser (2007) defined school violence as a process of doing any deliberate physical as well as non-physical (verbal) action or creating such condition which results in physical or non-physical discomfort in the person or persons getting it under the supervision of school(Chen, \& Astor, 2010). The process of teaching and learning gets affected negatively by school violence which results in anxiety and aggression in the victim. McGaha-Garnett (2013) found that violence creates disruptive behaviour, and aggression in teenagers and adolescents instead of progressing them academically. Teachers are considered the most significant members who can protect school from violence (Ansong, Okumu, Bowen, Walker, \& Eisensmith, 2017; Romero, Halln \& Cluver, 2019; Yavuzer, Gundogdu, \& Dikici, 2008). 
Pakistan is a developing country. Like other sectors, education sector is going through a transformation phase. Government of Pakistan has banned corporal punishment in schools by making legislation in this regard. Teachers can not punish students by law but they use alternate strategies to control students' undesirable behaviors and to put their attention towards their learning to improve their performance. These are the practices teachers are using commonly in many settings (Devries, et. al., 2019). Due to overcrowded classrooms teachers have to use strict classroom management strategies. They have to shout on students due to excessive noise in classroom. They are calling students' bad names to make them ashamed in order to keep them quiet. They are threatening students of failing to put their attention towards their lesson. These are common practices being used by majority of the teachers during teaching. The purpose of this study was to investigate the perceptions of teachers about the effects of these practices (which are actually related to physical and emotional violence) on students' academic performance.

\section{Objectives of the Study}

Following were the objectives of this study:

- To identify the perceptions of high school teachers about using practices related to physical and emotional violence.

- To identify the perceptions of high school teachers about the effects of using practices related to physical and emotional violence.

- To identify the difference in the perceptions of high school teachers about using practices related to physical and emotional violence on the basis of area.

- To find out the relationship between using practices related to physical and emotional violence and performance of students on the basis of teachers' perceptions.

\section{Research Questions}

This study answered the following research questions:

- What are the perceptions of high school teachers about using practices related to physical and emotional violence?

- What are the perceptions of high school teachers about the effects of using practices related to physical and emotional violence?

- Is there any difference in the perception of high school teachers about using practices related to physical and emotional violence on the basis of area?

Is there relationship between using practices related to physical and emotional violence and performance of students on the basis of teachers' perceptions?

\section{Research Methodology}

This study was proposed to identify the use and effects of teachers' practices related to physical and emotional violence on students' academic performance, through high school teachers' perceptions. Study was quantitative in nature and causal-comparative research design based on a cross-sectional survey was used. A self-developed and validated questionnaire was used as the instrument of the study to know teachers' perceptions about using different practices related to physical and emotional violence and their effects on students' academic performance. The instrument consisted of 30 items. Fifteen 15 items were about the use of practices related to physical and emotional violence and 15 items were about effects of using these practices on students' performance. Responses were rated on five point likert type scale from 'strongly agree 5' to 'strongly disagree 1'. A pilot study was conducted, Cronbach alpha coefficient of the questionnaire was 0.92. All the teachers of public high schools of Lahore city were the population of the study. A sample of 300 public high school teachers was selected through convenient sampling technique. Data were analyzed by using descriptive and inferential statistics ( $t$-test, Pearson Correlation coefficient and Regression analysis).

\section{Results}

Table one shows the descriptive statistics for the question:

What are the perceptions of high school teachers about using practices related to physical and emotional violence? 
Table 1: Summary statistics of perceptions of high school teachers about the practices they use in Classroom

\begin{tabular}{lcccc}
\hline & Min & Max & Mean & SD \\
\hline Shouting & 6.00 & 20.00 & 13.99 & 3.03 \\
Scaring & 7.00 & 25.00 & 16.60 & 4.11 \\
Beating & 4.00 & 20.00 & 13.41 & 3.43 \\
Mocking or Teasing & 3.00 & 15.00 & 10.13 & 2.76 \\
Total & 21.00 & 75.00 & 50.11 & 10.82 \\
\hline
\end{tabular}

Table one depicts the mean score of teachers' perceptions about the practices they use to manage their classroom during teaching. These practices included "scaring" which has highest mean scores $(\mathrm{M}=16.60, \mathrm{SD}=4.11)$ than "shouting" and "beating" $(\mathrm{M}=13.99, \mathrm{SD}=3.03 ; \mathrm{M}=13.41, \mathrm{SD}=3.43)$. On the other hand, the mean score of the practices related to "mocking or teasing" is lowest $(\mathrm{M}=10.13, \mathrm{SD}=2.76)$. Overall the perceptions of teachers showed that while teaching in the classroom they had to use these practices to maintain discipline and to improve students' learning and performance. The total mean score $(\mathrm{M}=50.11, \mathrm{SD}=10.82)$ for using practices (shouting, scaring, beating, mocking or teasing) have a worth mentioning high value which shows the significant use of these practices which are actually related to physical and emotional violence. Hence, it is concluded that in the light of teachers' perceptions it is inferred that high school teachers are using practices related to physical and emotional violence but they think that they have to use these practices to maintain discipline and focus their attention towards their learning and performance.

Table 2: Summary of teachers' perceptions about the effects of physical and emotional violence on students' academic performance

\begin{tabular}{lcccc}
\hline \multicolumn{1}{c}{ Variables } & Min & Max & Mean & SD \\
\hline Improvement in Performance & 6.00 & 20.00 & 13.99 & 3.03 \\
Attention towards Learning & 7.00 & 25.00 & 16.60 & 4.11 \\
Helpful in Learning & 4.00 & 20.00 & 13.41 & 3.43 \\
Correcting the Undesired Behaviors & 3.00 & 15.00 & 10.13 & 2.76 \\
Total & 21.00 & 75.00 & 50.11 & 10.82 \\
\hline
\end{tabular}

Table 2 depicts that the mean score of teachers' perceptions about the effects of practices related to physical and emotional violence on students" "attention towards learning" was the highest $(\mathrm{M}=16.60, \mathrm{SD}=4.11)$ than "improvement in performance" and "helpful in learning" $(\mathrm{M}=13.99, \mathrm{SD}=3.03 ; \mathrm{M}=13.41, \mathrm{SD}=3.43)$. On the other hand, the mean score of the subscale "correcting the undesired behaviors" is the lowest $(\mathrm{M}=10.13, \mathrm{SD}=2.76)$. Total mean score showed that teachers had strong perceptions that these practices had significant effects on students' academic performance $(\mathrm{M}=50.11, \mathrm{SD}=10.82)$. Hence, it is concluded that according to the perceptions of high school teachers they were using these practices because they believed that these were helpful to improve their performance, take their attention towards learning, helpful in learning and to correct undesirable behaviors and they thought that physical and emotional violence had positive effect on students' academic performance.

Table 3: Independent sample t-test to identify difference between male and female high school teachers' perceptions about physical and emotional violence

\begin{tabular}{lccccccc}
\hline Variable & Gender & $N$ & $M$ & $S D$ & $T$ & $d f$ & $P$ \\
\hline Physical and Emotional Violence & Male & 204 & 49.77 & 9.51 & 2.38 & 298 & .019 \\
& Female & 96 & 53.05 & 11.84 & & & \\
\hline
\end{tabular}

Table three represents that the mean score for female $(\mathrm{M}=53.05, \mathrm{SD}=11.84)$ was greater than the mean score for male high school teachers $(\mathrm{M}=49.77, \mathrm{SD}=9.51)$. The difference was statistically significant between the perceptions of male and female high school teachers at the $\mathrm{p} \leq .05$ level of significance $(298)=2.38, \mathrm{p}=.019$. Hence, it is concluded that female high school teachers were using more physical and emotional violence against their students 
than the male high school teachers.

Table 4: Independent sample t-test to know difference in high school teachers' perceptions working in rural and urban areas about physical and emotional violence

\begin{tabular}{lccccccc}
\hline Variable & Locale & $N$ & $M$ & $S D$ & $t$-test & $d f$ & $p$ \\
\hline Physical and Emotional Violence & Urban & 294 & 50.83 & 10.49 & .25 & 298 & .813 \\
& Rural & 6 & 50.33 & 4.72 & & & \\
\hline
\end{tabular}

Table 4 illustrates that the mean score for urban $(M=50.83, S D=10.49)$ was almost similar to the mean score for rural areas teachers at high schools $(M=50.33, \mathrm{SD}=9.51)$. It is evident that the difference between the perceptions of teachers working in urban and rural areas in high schools was not statistically significant at $p \geq .05$ level of significance $(298)=.25, \mathrm{p}=.813$. It may be inferred that the urban and rural areas teachers were at the same level of physical and emotional violence against their students at high schools.

Table 5: Relationship of physical and emotional violence with the performance of students at high schools

\begin{tabular}{llcc}
\hline & Variables & 1 & 2 \\
\hline 1 & Physical and Emotional Violence & - & $.828 * *$ \\
2 & Performance of Students & - \\
\hline
\end{tabular}

$* * \mathrm{p}<0.01$

Table 5 showed the results of correlation analysis which revealed that the physical and emotional violence used by teachers was positively correlated with the academic performance of their students at high school level $\mathrm{r}=.828(\mathrm{p}<0.01)$. Based on the perceptions of the teachers, it is concluded that the physical and emotional violence against students improves their academic performance.

Table 6: Regression analysis regarding the physical and emotional violence predicting students' academic performance

\begin{tabular}{|c|c|c|c|}
\hline \multirow[t]{2}{*}{ Variables } & & \multicolumn{2}{|c|}{ Students' Academic Performance } \\
\hline & B & $\mathrm{T}$ & $\mathrm{P}$ \\
\hline $\begin{array}{l}\text { Physical and Emotional } \\
\text { Violence }\end{array}$ & $.828 * *$ & 25.52 & .000 \\
\hline $\mathrm{R}^{2}$ & 68.6 & & \\
\hline
\end{tabular}

Results in the given table depict the physical and emotional violence explaining $69 \%$ of the variance in the dependent variable which is student academic performance. Physical and emotional violence made a statistically significant contribution to the students' academic performance. Hence, it is concluded that the physical and emotional violence is significantly predicting academic performance of students at high schools level.

\section{Conclusion}

This study was designed to identify teachers' perceptions about the effect of practices related to physical and emotional violence i.e. shouting, scaring, beating and mocking or teasing on the students' academic performance. On the basis of data analysis it is concluded that teachers are frequently using different practices related to physical and emotional violence. Teachers told that they had to use these practices to maintain discipline and focus students' attention on their learning and improve their performance. They have to shout in class in order to stop students to make a noise. Due to overcrowded classrooms it is difficult for teachers to keep an eye on and interact with each student. While attending a student, other students start talking to one another. It creates a difficult situation for a teacher and they have to shout in order to keep them silent. In our local context it is common that students have developed some personal problems or they get personal on some classroom matters. They develop personal grievance and start confronting with each other. To stop students from fighting with one another, teachers mostly use the strategies of scaring them. Although scaring put a negative effect on students' intellectual and personal development but teachers have to use scaring practices in order to control students. In some serious cases when teachers remain helpless in controlling students' unbearable 
behavior they have to beat them. Teachers told that while realizing the severity of students'behaviors they have to use harsh words which is disrespectful but they have to do so because students are not following them.

Results also revealed that female teachers use more practices related to physical and emotional violence against their students as compared to male teachers. Moreover, responses of teachers working in urban and rural areas showed that at both type of areas, teachers' are using practices related to physical and emotional violence. The most important finding of the study is that teachers' responses revealed a positive correlation among using practices related to physical violence and academic performance of students which may lead them to use these practices more and more to enhance their students' performance up to a targeted level.

\section{Recommendations}

On the basis of the findings of the study, following recommendations are made:

- Most of the teachers have to use practices related to physical and emotional violence in order to maintain discipline and control undesirable behaviors. In this regard teacher may play a role of mentor and guide to involve students in disciplinary problems so that they may feel themselves responsible to maintain discipline.

- Teachers may try to improve students' academic performance through the use of collaborative consultations with students about their problems instead of physical and emotional violence.

- Educational authorities may arrange awareness programs and campaigns for the active participation of teachers, and parents to highlight negative effects of physical and emotional violence and suggest alternative healthy strategies to get desirable results.

- Different training and support programs may be introduced by educational administration to make teachers enable to improve their students' academic performance by using non-violent behavior strategies.

\section{References}

Akiba M. (2002). Student victimization: National and school system effects on school violence in 37 nations. American Educational Research Journal, 39(4), 829-853.

Coleman, J.S. (1966). Equality of educational opportunity study. Washington, DC: U.S. Department of Health, Education, and Welfare, Office of Education/National Center for Education Statistics.

Crawage, M. (2008). How resilient adolescent learners in a township school cope with school violence: a case study (Doctoral dissertation, University of Johannesburg).

Elliot, D.S., Hamburg, B. \& Williams, K.R. (1998).Violence in American schools. Cambridge University Press. Flannery, J.D. (2006). Violence and mental health in everyday life, AltaMira Press.

Hoffman, A.M. (1996). Schools, violence and society.Praeger Publishers: CT: WestPort.

McGaha-Garnett, V. (2013). The Effects of Violence on Academic Progress and Classroom Behavior: From a Parent's Perspective. Ideas and Research You Can Use: VISTAS. Retrieved from https://www.counseling. org/docs/defaultsource/vistas/the-effects-of-violence-on-academicprogress-and-classroom-behavior.pdf.

Prinsloo, J., \&Neser, J. (2007).Operational assessment areas of verbal, physical and relational peer victimisation in relation to the prevention of school violence in public schools in Tshwane South ActaCriminologica: Southern African Journal of Criminology, 20(3), 46-60.

Şahbal, A. R. A. S., Sema, Ö. Z. A. N., \&Sevgi TIMBIL, S. Ş. (2016). Exposure of students to emotional and physical violence in the school environment.NöroPsikiyatriArşivi, 53(4), 303-310.

Yavuzer, Y., Gundogdu, R., \&Dikici, A. (2008).Teachers' perceptions about school violence in one Turkish city.Journal of school violence, 8(1), 29-41.

Morales Vasco, M. L. (2019). A phenomenological interpretation of violence in children's everyday life. Sophia, 15(1), 73-82.

Herrero Romero, R., Hall, J., \& Cluver, L. (2019). Exposure to violence, teacher support, and school delay amongst adolescents in South Africa. British journal of educational psychology, 89(1), 1-21. 
Chen, J. K., \& Astor, R. A. (2011). Students' personal traits, violence exposure, family factors, school dynamics and the perpetration of violence in Taiwanese elementary schools. Health education research, 26(1), 150166.

Devries, K. M., Fabbri, C., Allen, E., Barongo, V., Shayo, E., Greco, G., ... \& Rodrigues, K. (2019). Preventing violence against children in schools (PVACS): protocol for a cluster randomised controlled trial of the EmpaTeach behavioural intervention in Nyarugusu refugee camp. BMC public health, 19(1), 1-10.

Beyene, A. S., Chojenta, C., Roba, H. S., Melka, A. S., \& Loxton, D. (2019). Gender-based violence among female youths in educational institutions of Sub-Saharan Africa: a systematic review and meta-analysis. Systematic reviews, 8(1), 1-14.

Anderson, C. A., Berkowitz, L., Donnerstein, E., Huesmann, L. R., Johnson, J. D., Linz, D., ... \& Wartella, E. (2003). The influence of media violence on youth. Psychological science in the public interest, 4(3), 81-110.

Ansong, D., Okumu, M., Bowen, G. L., Walker, A. M., \& Eisensmith, S. R. (2017). The role of parent, classmate, and teacher support in student engagement: Evidence from Ghana. International Journal of Educational Development, 54, 51-58.

Ward, C. L., Artz, L., Leoschut, L., Kassanjee, R., \& Burton, P. (2018). Sexual violence against children in South Africa: A nationally representative cross-sectional study of prevalence and correlates. The Lancet Global Health, 6(4), e460-e468.

Chen, J. K., \& Avi Astor, R. (2010). School violence in Taiwan: Examining how Western risk factors predict school violence in an Asian culture. Journal of Interpersonal Violence, 25(8), 1388-1410. 